\title{
ABOUT MARKETING STRATEGY FOR WINE ROUTE. CASE STUDY - CONSTANTINOPLE WINE ROUTE
}

\author{
Mirjana Maksimović ${ }^{1}$ \\ Tatjana Pivac ${ }^{2}$ \\ Anđelija Ivkov-Džigurski ${ }^{3}$ \\ Kristina Košić ${ }^{4}$
}

DOI: https://doi.org/10.31410/tmt.2019.685

\begin{abstract}
The main goal of this paper is to present the diversity of the tourist offer of the Constantinople Wine Route (CWR). The paper contains PESTEL and SWOT analysis, two of the best strategic management techniques and research analysis through questionnaire that actually indicate how interested respondents are in wine tourism in Serbia, how much experience they have about it, and whether they are aware of the Constantinople Wine Route. The survey was conducted on the basis of random sample, in the territory of Serbia. At the very end, the results of this survey were crossed with those of interviewed winery owners about what their wineries can offer to tourists and what their expectations are from participating in this project. Cross-referenced analysis opens up new areas for research, but also provides clear guidance on how to communicate the tourist offer of the Constantinople Wine Route.
\end{abstract}

Keywords: Wine, Wine Tourism, Cultural Route, Constantinople Wine Route.

\section{INTRODUCTION}

Constantinople Wine Route is a new wine tourism project in the Balkans. The initiative comes from Serbia, and with this route, besides Serbia, Bulgaria and the European part of Turkey (Thrace) are also connected. Originally, this route was established by the Romans in 33 A.D., who built Via Militaris, a route that was primarily used to navigate their legions. In the Middle Ages, this route became the main trade and military link between Asia and Europe, changing its name to the Constantinople Route. This route was used by travellers, travel writers, merchants, bandits, pilgrims and many others. Using this route, the Romans brought the first vine seedlings to the Old Continent. Centuries later, using the Constantinople Route, the Turks went to conquer Europe. Many historically important events are related to this route, but also to wine. For example, it is noted that the Serbian Grand Prince Stefan Nemanja, welcoming Holy Roman Emperor Frederick I Barbarossa in Nis, served his guest wine and mead. In 1433, the French travel writer Berntrandon de la Broquière (De la Broquière, 2002) also travelled on the Constantinople Route, and his subsequently published travel book "Travel over the sea" testifies that "at the time Serbian wine was better than French".

The Constantinople Route connects Belgrade (then Singidunum), Nis, Pirot, Dimitrovgrad, Sofia, Plovdiv and Istanbul, (then Constantinople) (Zirojević, 1970). Although most of the route is locat-

$1 \quad$ Association Women and Wine, Kumodraška 114, Belgrade, Serbia

2 University of Novi Sad, Faculty of Sciences, Department of Geography, Tourism and Hotel Management, Trg Dositeja Obradovića 3, Novi Sad, Serbia

3 University of Novi Sad, Faculty of Sciences, Department of Geography, Tourism and Hotel Management, Trg Dositeja Obradovića 3, Novi Sad, Serbia

4 University of Novi Sad, Faculty of Sciences, Department of Geography, Tourism and Hotel Management, Trg Dositeja Obradovića 3, Novi Sad, Serbia 
ed in Serbia, a country with a long viticulture tradition, the part of the route that passes through Bulgaria and Turkey, is not of less importance, especially the part that goes through the Thracian region, which is located in both countries. This part of the route is considered to be one of the oldest viticulture regions in the world and is about 7000 years old (Ivanova et al, 2017). It is interesting to note that the Turkish part of Thrace has its own route called "Thrace Wine Route" which is also the first wine route in Turkey (Akdag et al, 2017; Maksimović et al, 2019).

\section{MARKETING IN WINE TOURISM}

Wine tourism is a relatively new type of tourism in the Balkans. When we talk about the Constantinople Wine Route, which connects Belgrade and Istanbul, that is, Serbia, Bulgaria and Turkey, we are talking about regions where people have been involved in viticulture for thousands of years. However, all three countries have only recently appeared on the wine map of the world as wine tourist destinations. The existence of a wine route, based on a striking common past, rich in cultural and historical heritage, similar, yet completely different gastronomy, viticulture that nurtures a completely different autochthonous assortment, but also completely different styles of wine of international and regional varieties, cultural, religious and ethnological diversity, can make the promotion of wine tourism in all three countries a lot easier. In general, wine routes, as clearly defined routes, help facilitate the branding of a wine destination, while at the same time facilitating orientation and movement for tourists. Furthermore, it is a fact that clearly defined wine routes enrich the tourist product, create greater engagement of people in rural areas, prolong the tourist season, accelerate economic development, facilitate promotion, enhance the image, revitalise the village and the similar (Marzo-Navarro \& Pedraja-Iglesias, 2009; Blazheska \& Nickova, 2016; Fernández et al, 2018).

The primary goals of every business, including wine tourism, are survival, profitability and growth (Cant et al, 2007). To fulfil these goals, wineries interested in wine tourism have to develop a valuable and profitable relationship with visitors (Kotler \& Armstrong, 2006). This can be achieved in many ways, wine routes are probably one of the most promising because, although wine is the most important component of wine tourism (Alebaki \& Iakovidou, 2011), wine tourism is much more than simply enjoying a glass of good wine (Mitchell, 2006). Hall and Mitchell called this phenomenon "tourist terroir" in an attempt to explain the physical, cultural and natural specificity that makes a wine region or in our case a route a unique tourist experience (Hall \& Mitchell, 2002).

\section{PESTEL ANALYSIS}

PESTEL analysis is the analytical method of the business environment and is the basis of all strategic planning. PESTEL analyzes the environment and is used for both emerging and existing markets, and provides an overview of the situation that can significantly affect the development of wine tourism. Also, this analysis provides an overview of the external factors that may affect wine tourism globally, as well as a more serious introspective overview of wineries within the observed area (Gregorić, 2014).

The name PESTEL is an acronym for English words that define the elements that serve the analysis: Political, Economic, Social, Technological, Ecological and Legal factors. Considering the fact that all these factors can crucially affect the success of a start-up project such as the Constantinople Wine Route, it is logical to opt for such analysis, which will subsequently be cross-checked against the information obtained by SWOT analysis. 


\section{Political factors}

\begin{tabular}{|l|l|}
\hline \multicolumn{1}{|c|}{ ADVANTAGES } & \multicolumn{1}{c|}{ D ISA DVA NTAGES } \\
\hline $\begin{array}{l}\text { Stable security situation in the country and } \\
\text { region }\end{array}$ & $\begin{array}{l}\text { Political instability in the country } \\
\text { Potential disinterest of people in responsible } \\
\text { positions to develop new idea }\end{array}$ \\
$\begin{array}{l}\text { Solid relations between countries on the CWR } \\
\text { route }\end{array}$ & $\begin{array}{l}\text { Lack of confidence in the system } \\
\text { - The process of joining the EU has started } \\
\begin{array}{l}\text { Teveloping the CWR idea } \\
\text { The existence of TO Serbia }\end{array}\end{array}$ \\
\hline
\end{tabular}

Economic factors

\begin{tabular}{|l|l|}
\hline \multicolumn{1}{|c|}{ ADVANTAGES } & \multicolumn{1}{c|}{ DISADVA NTAGES } \\
\hline - Currency stability & - Slow return on invested capital \\
- Creating new jobs & - Unstable market \\
& $\begin{array}{l}\text { Few funds are invested in tourism } \\
\text { development in smaller municipalities }\end{array}$ \\
\hline
\end{tabular}

\section{Social factors}

\begin{tabular}{|l|l|}
\hline \multicolumn{1}{|c|}{ ADVANTAGES } & \multicolumn{1}{c|}{ DISA DVA NTAGE S } \\
\hline - Traditional hospitality of the population & - Negative birth rate \\
- Long and rich tradition & Expressed passivity of the local population \\
- Interest of foreign tourists to discover new & - Insufficient education of the local population \\
destinations & - Insufficient knowledge of foreign languages \\
\hline
\end{tabular}

\section{Technological factors}

\begin{tabular}{|c|c|}
\hline ADVANTAGES & DISA DVANTAGES \\
\hline $\begin{array}{l}\text { - Use of new technologies in production } \\
\text { - Simultaneous use of traditional technologies in } \\
\text { production } \\
\text { - Introduction of information technology } \\
\text { - Investing in the construction of new facilities }\end{array}$ & $\begin{array}{l}\text { - Inexperience in working with new } \\
\text { technologies } \\
\text { - Poor road infrastructure in some destinations } \\
\text { - Insufficient use of the Internet for marketing } \\
\text { purposes }\end{array}$ \\
\hline
\end{tabular}

\section{Ecological factors}

\begin{tabular}{|c|c|}
\hline ADVANTAGES & DISADVANTAGES \\
\hline $\begin{array}{l}\text { - Developed environmental awareness } \\
\text { - Relatively preserved nature } \\
\text { - Increasing status of eco wine on the market } \\
\text { - Development of new wine varieties } \\
\text { favorable for organic production }\end{array}$ & $\begin{array}{l}\text { - High cost of producing organic wines } \\
\text { - Insufficient knowledge of newly created } \\
\text { wine varieties } \\
\text { - Existence of wild dumps }\end{array}$ \\
\hline
\end{tabular}

\section{Legal factors}

\begin{tabular}{|l|l|}
\hline \multicolumn{1}{|c|}{ ADVANTAGES } & \multicolumn{1}{c|}{ DISA DVA NTAGE S } \\
\hline - Ability to quickly register a legal entity & $-\begin{array}{l}\text { Non-compliance with laws and other legal } \\
\text { acts }\end{array}$ \\
$\begin{array}{l}\text { Harmonization of standards and regulations } \\
\text { with the EU }\end{array}$ & $\begin{array}{l}\text { Poor citizens' confidence in the state's legal } \\
\text { system }\end{array}$ \\
$\begin{array}{l}\text { Incentive measures for rural development } \\
\text { To adopt a new law on tourism that regulates } \\
\text { the issue of accommodation in rural tourism }\end{array}$ & $\begin{array}{l}\text { Laws that are more demanding than EU law } \\
\text { (organic production example) }\end{array}$ \\
\hline
\end{tabular}




\section{Political factors}

When it comes to political factors it is very important to highlight the stable political situation in all three countries on the CWR route, as well as their mutual relations. However, the Serbian Law on Tourism (adopted in 2019), as well as the Tourism Development Strategy of Serbia 2016-2025, have absolutely no knowledge of the term wine tourism. According to these two documents, wine tourism may eventually be classified as rural tourism, which is not considered wrong but not good enough. The recent establishment of the Association of Winegrowers and Viticulturist of Serbia, as well as the announced development of the Strategy for the Development of Winegrowing and Viticulture, may have a potential impact on better position of wine tourism in Serbia, but there remains a problem of mistrust in the system as well as a dilemma regarding the equal treatment of all interested entities.

\section{Economic factors}

Recognizing the importance of wine tourism in the Law on Tourism and the Tourism Development Strategy of Serbia, would allow greater investments in this branch of tourism, but also regulate the system of work. Thus, wine tourism often stays in the so-called "gray zone" of which neither the state nor the winemakers have an interest. The state does not collect taxes on wine tourism, and does not invest in the development of this branch of tourism.

\section{Social factors}

None of the three countries, Serbia, Bulgaria and Turkey, as countries in the CWR route, exist on the wine map of the world as recognizable tourist destinations. On the other hand, they can be of particular interest to tourists of distant markets, as it allows them to visit more countries, get acquainted with more cultures, peoples and traditions, but also experience completely different wines and gastronomy, all in just one trip. Moreover, for European tourists, the CWR route, which can also be observed as the "breath of the Orient in Europe", may seem completely exotic and interesting.

\section{Technological factors}

Throughout the CWR route there are very small, family-owned wineries which in an attempt to preserve tradition can make technologically debatable wines, but also there are large, profit-oriented wineries that clearly understand the needs of the modern market and are able to respond in style, quality and quantities. For both, there is often a lack of strategically driven market communication. The solution to both problems lies in education.

\section{Ecological factors}

The global and domestic markets are becoming more environmentally conscious and, accordingly, eco-produced wines are gaining the importance. Insight into the wine offer of the CWR route reveals a small number of organically produced wines. The reason for this lies in the lack of information on market trends, but also in new grape varieties intended primarily for organic production. 


\section{Legal factors}

Although, in legal terms, there is the unresolved issue of wine tourism, the new Law on Tourism of the Republic of Serbia, passed in 2019, regulated the issue of accommodation in rural tourism. For now, it remains an open question to implement it, but also the complicated procedure regarding certification in organic production.

\section{SWOT ANALYSIS}

Bringing together the strengths and weaknesses of the Constantinople Wine Route, with chances and threats in the environment, it can be decided to choose the best strategy for the development of this wine tourism project. This is assisted by SWOT analysis, one of the best strategic management techniques, named after the initial letters of four English words: Strengths, Weaknesses, Opportunities and Threats. SWOT analysis is a tool for understanding the situation according to which the current strongest and weakest points of the project, total potential, space for development can be identified, but also reveal real threats to the successful realization of the whole project.

The main advantage of SWOT analysis is its simplicity in observing the positive sides of the Constantinople Wine Route and at the same time in identifying some potentially negative aspects that may threaten the new wine tourism project. Likewise, through the positive and negative aspects, the present and the possible future of the project are easily perceived.

\begin{tabular}{|c|c|}
\hline Strengths & Weaknesses \\
\hline $\begin{array}{l}\text { - Original and attractive tourist offer } \\
\text { - Long and rich tradition of wine production } \\
\text { - } \text { Authentic and quality wines } \\
\text { - Healthy and original food } \\
\text { - Rich historical heritage } \\
\text { - Positive attitude of all stakeholders }\end{array}$ & $\begin{array}{l}\text { - Disloyal competition } \\
\text { - Unrecognized wine tourist destination } \\
\text { - Uneven wine quality } \\
\text { - Lack of team spirit } \\
\text { - Problems in financing startups }\end{array}$ \\
\hline Opportunities & Threats \\
\hline $\begin{array}{l}\text { - Status of the project of national importance } \\
\text { - Familiarizing the market with the rich } \\
\text { historical heritage of the entire route } \\
\text { - The new life of medieval gastronomy } \\
\text { The recognition of Serbia as an attractive } \\
\text { tourist destination } \\
\text { - Creating positive publicity }\end{array}$ & $\begin{array}{l}\text { - } \text { Creating positive publicity } \\
\text { - Political instability in the country and the } \\
\text { region } \\
\text { - Poor cooperation among all actors involved } \\
\text { - Lack of tourists } \\
\text { - Problems with project financing }\end{array}$ \\
\hline
\end{tabular}

The Constantinople Wine Route, as an original and historically extremely powerful new tourist offer, is of great interest to both expert public and tour operators. The fact that all three countries on the CWR route have a millennial tradition in wine production, and are still on the sidelines of wine tourism globally, makes this route interesting and under-researched. Authentic gastronomic and wine offer are an important factor and a precondition for the success of wine tourism. Because of all this, the Constantinople Wine Route has the potential to become a wine tourism project of national importance. All that is needed the support of the ministry in charge and a well-conducted media campaign. Launched on the private initiative of a group of wine tourism enthusiasts, the Constantinople Wine Route project faces the problem of financing a marketing campaign aimed at clearly defined target groups. 


\section{METHODOLOGICAL SETTINGS AND ANALYSIS OF RESULTS}

For the purpose of this paper, two studies have been done. Crossing the results of both surveys will open new areas for research, as well as provide clear guidance on how and by what channels to communicate this tourist offer.

\subsection{Interviews with winemakers and/or winery managers on the CWR route}

The first research was done by the method of semi-structured interview with the owners or managers of all 19 wineries located on the Serbian part of the Constantinople Wine Route, and which are potential partners in the project of establishing a new wine route. The goal of interviewing winemakers was to clearly define the tourist wine offer of CWR, as well as to indicate their expectations from partners in this project.

The results of this research showed that most wineries on the route have the necessary capacities for the development of wine tourism, some are in preparation and will soon be ready to receive the first tourists, and some currently do not have the desire or ability to develop tourism potential. Wine tourism capacities primarily include the existence of wine cellar and vineyards that can be visited, as well as a tasting room and toilet for winery guests. The offer includes also smaller wineries, which meet the four above mentioned criteria. The fact that small wineries cannot offer their guests top service, luxury and prestige in the way they present their wineries, but instead they offer that unique sense of warmth, cordiality and often family heritage so characteristic of small businesses. It is interesting to point out that, when asked what they expected from participation in the project of the Constantinople Wine Route, all respondents subsequently answered "increase in the number of tourists and better sale of wine at the winery". This response, although expected, seems at the same time a bit disappointing because, aimed at their own prosperity, winemakers do not see the wider potential of wine routes when it comes to the whole region. The reason for this attitude lies possibly in the fact that most winemakers built their entire capacities with their own resources and without much support from the state and local government.

\subsection{Survey of potential wine tourists}

The second research is based on a survey questionnaire of potential wine tourists. The aim of the questionnaire was to indicate the degree of awareness of potential wine tourists in the overall wine tourism offer of Serbia, as well as the awareness of a new wine tourism project called the Constantinople Wine Route. The questionnaire consisted of 19 questions: 7 questions related to creating insights into the demographic picture of respondents, 5 questions provided an overview of travel habits and motives, 4 related to travel information habits and the organization of travel, while the last 3 questions related exclusively to wine tourism. The questionnaire was distributed exclusively electronically, via mail and social networks, and exclusively in the territory of Serbia. The questionnaire was created using Google Forms, a specialized online data collection tool. In order to avoid a situation where one user answers multiple times, the questionnaire could be accessed only once from each mail address. Responses were collected during September 2019. The questionnaire was completed anonymously.

The sample consists of s total of 1084 respondents, $64 \%$ are women and $36 \%$ are men. Reasons for the two-thirds dominance of women in this sample of respondents should be sought in the 
area of consumer behaviour (Booth et al, 2014), where women have been proven to be less risky when it comes to jobs, money, but also their families. We can conclude that women bear most of the decision to choose holiday and travel destinations. Just over half of the respondents are between 20 and 40 years old (53\%), and a significant number are between 40-60 years old (40\%). $42 \%$ of respondents have university degree, $32 \%$ of respondents have master's degree, and a third of respondents $(32 \%)$ have a secondary education. The questionnaire was also completed by $27 \mathrm{PhDs}$, accounting for $3 \%$ of the total sample. $81 \%$ of the respondents are employed, which corresponds to the age category, but also to the stable monthly income (Table 1).

Table 1. Demographic data on respondents (the first part)

\begin{tabular}{|l|c|}
\hline Gender & $\mathbf{\%}$ \\
\hline M & 36 \\
\hline Age & 64 \\
\hline Up to 20 & $\mathbf{\%}$ \\
\hline $21-40$ & 1 \\
\hline $41-60$ & 53 \\
\hline Over 60 & 40 \\
\hline Education & 6 \\
\hline Primary school & $\mathbf{\%}$ \\
\hline Secondary school & 1 \\
\hline College or bachelor's degree & 32 \\
\hline Master's degree & 42 \\
\hline PhDs & 22 \\
\hline Place of living & 3 \\
\hline village & $\mathbf{\%}$ \\
\hline city & 15 \\
\hline Profession & 85 \\
\hline University student & $\mathbf{\%}$ \\
\hline Employed & 5 \\
\hline Unemployed & 81 \\
\hline Retired & 9 \\
\hline
\end{tabular}

When it comes to monthly income and money in general, it is interesting to point out the diversity of the survey sample, in which $30 \%$ of respondents claim to have income from 40.000 to 60.000 dinars per month, $18 \%$ receive 60.000 to 80.000 dinars, $17 \%$ from 20.000 to 40.000 dinars, $17 \%$ over 100.000 dinars, $10 \% 80.000$ to 100.000 dinars, while $7 \%$ of respondents report less than 20.000 dinars of monthly income. Furthermore, 52\% of them are married and $85 \%$ of respondents live in urban areas (Figures 1 and 2).

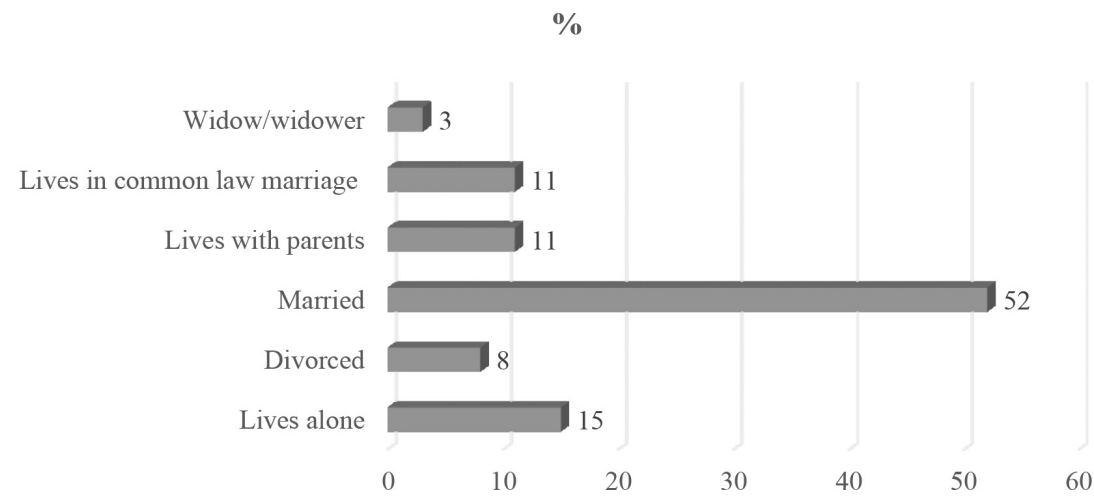

Figure 1. Marital status of respondents 


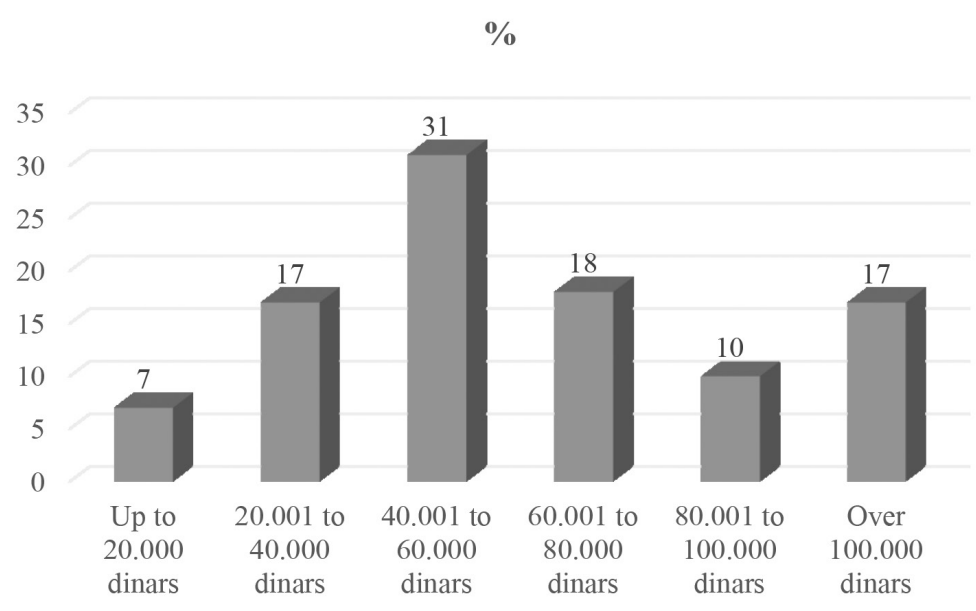

Figure 2. Monthly income of respondents

When it comes to travel habits, as the most frequent destinations to visit $44 \%$ of the respondents cite the sea, $33 \%$ of the respondents cite cities, while the mountains are in the third place $(12.5 \%)$, rural areas in the fourth (8\%), and spas in the last place (3\%). Most respondents travel with their spouse and children (38\%), which is logical since $52 \%$ of them are married, $27 \%$ go on vacation only with a partner, while friends are placed in the third place $(23 \%)$. The percentage of those who travel alone (9\%) is not negligible, which can be an interesting market niche for tour operators, especially considering the fact that only $13 \%$ of respondents always use the service of travel agencies for the organization of travel. It is also interesting to note that $17 \%$ of the respondents use the service only for the organization of holidays, but not for the weekend trips. $37 \%$ of them use the services of travel agencies occasionally, and 33\% never use the services of travel agencies (Figure 3). These decisions raise a number of questions on the topic of travel agencies, as it would certainly be interesting to identify the reasons for avoiding them. Also, profit that agencies lose in this way is not insignificant if one considers that the price of organized travel is often lower than individual ones. Reasons for tendency towards individual travel organization should also be sought in easy access to information with the help of internet, web platforms for hotel reservations, the purchase of airline tickets and other tickets.

\section{Do you use services of travel agencies for weekend trip} organization?
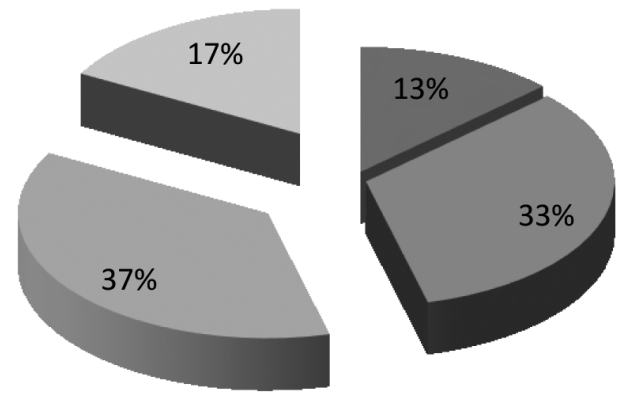

yes, always

only for the organization of holidays

occasionally

never use the services

Figure 3. Graphical representation of respondents' answers on the topic of travel agencies

Further, as a quite logical choice, there is a tendency to travel with one's own vehicle when weekend trips are mentioned (73\%), while only $18 \%$ choose organized transport and $9 \%$ public transport. Such choices also raise the issue of safety when it comes to wine tourism because we know that driving and wine do not go together. Also, the need for medium and long-term projections for the development of wine tourism, the issue of transportation and travel organization 
puts this issue at the forefront when it comes to the way of making a profit from wine tourism, especially from the aspect of wine tourism intermediaries.

The Tourism Development Strategy for the period between 2016 and 2025 adopted by the Government of the Republic of Serbia recognizes the wine tourist as the tourist who spends more money (https://mtt.gov.rs/download/3/strategija.pdf). It's true that this fact was not enough for wine tourism to enter the above-mentioned Strategy as a branch of tourism, while on the other hand scientific researches clearly testify to this attitude regarding wine tourists (Pratt, 2014). When it comes to Serbia, $42.5 \%$ of respondents state that they are ready to spend up to 5.000 dinars per person for a weekend trip. $33 \%$ of respondents think that up to 10.000 dinars is more realistic, $15 \%$ of them are ready to spend up to 15.000 dinars for the same thing, and only $10 \%$ of them fall into the category of people who would spend over 15.000 dinars for a weekend trip. If we connect this with the fact that, as they stated earlier, in most cases people travel in pairs (27\%) or family $(38 \%)$, then it is a logical decision to spend less money per person, because the money certainly comes from the same budget.

When it comes to wine tourism, $58 \%$ of respondents admit that they have no experience with visits to wineries, $39 \%$ were sometimes in a winery, while $3 \%$ of respondents consider themselves a good connoisseur of wine tourism potential in Serbia. With further insight, $76 \%$ stated that they would be very happy to visit one of the Serbian wineries because they primarily expect "an interesting, original and informative experience" from their travels (70\%). The remaining $24 \%$ of respondents categorically refuse to visit wineries because they believe wine is not their area of interest.

Respondents gave the answer to the question how to communicate the wine tourist offer by answering how to get information about tourist offers, where the majority of them stated that information was obtained exclusively through social networks (49\%), 23\% via print and electronic media, $20 \%$ used other sources, while only $5 \%$ received information from travel agencies.

Last but not least, only $16.5 \%$ of the respondents heard about the existence of a new wine route called the Constantinople Wine Route. How good or bad the result is, depends from the angle the problem is observed. If we start from the fact that The Constantinople Wine Route is promoted almost exclusively on social networks and significantly less in electronic and print media, and we have seen that respondents receive information about new tourist offers mainly through these two channels of communication ( $72 \%$ in total), then we must not be satisfied with what we have achieved. On the other hand, if we take into consideration that all the promotion of this wine route is based on the enthusiasm of one person and virtually no budget, then the result is not so bad. All in all, on the basis of this information which testifies on properly selected channels of communication further decisions can be made. What is missing here is a more aggressive performance which to certain extent depends on available budget, and no less significant is the virtually non-existent synergetic effect in which the participating wineries in the project are expected to contribute more to the promotion of the Constantinople Wine Route, primarily through their personal and business profiles on networks.

\section{CONCLUSION}

The research conducted for the purpose of this paper, as stated in the analysis of the results, has raised many questions. When it comes to the research of wider population, some of them, such as: the influence of women in the travel decision-making process, exploring channels of communication with potential wine tourists (which networks, which electronic and print media to use) and 
research into travel motives, deserve to be given extra attention. The results of these studies would make a significant contribution to understanding the needs of consumers, in this case of potential wine tourists, and open up new, more precisely defined, channels of communication through which information on wine tourism offers would reach them. This is especially important because with this research we found out that although they do not know much about it, respondents are largely open to new knowledge that will bring them, as they stated in most cases (70\%) "Interesting, original and informative experience". Given the previous (in)experience in wine tourism, the Constantinople Wine Route may be just that. When it comes to winemakers and winery managers, interviews indicated that they were more oriented on sale than on marketing activities, lacking understanding and good enough sense of connection between the two sectors. Also, social networks, originally social media, perceive wineries in Serbia more as a bulletin board than as a medium that they have the power to edit themselves. Likewise, they do not understand that social networks allow constant two-way communication with their target group and so not make sufficient use of this potential. The marketing strategy for Constantinople Wine Route must strive to promote understanding between wineries and government, establishing standards for the industry of wine tourism, raising the skill level of employees in the wine tourism and improving the relationship between lifestyle, travel habits, food and wine. The obligation imposed by the law on the association of viticulturists in regional associations, primarily in order to exercise the right of protection of geographical origin for their wines, is finally starting to give results. The Association of Viticulturists and Winemakers of Sumadija is a good example of internal communication, cooperation and mutual support. A bit younger in experience, but also a good example of association are members of the Association of viticulturists and winemakers of Srem - Fruska Gora. These two examples of good practice give hope that wineries united around a new wine tourism project called the Constantinople Wine Route will find ways to achieve, at this point more than necessary synergetic effect.

\section{REFERENCES}

Akdag, G., Oyan, S., Kastenholz, E. (2017). Motivators for participating in Wine Tourism Activities - the case of Tourists on the Thrace Wine Route in Turkey. Revista Turismo \& Desenvolvimento, N²7/28, 85-87, ISSN: 2182-1453

Alebaki, M. \& Iakovidou, O. (2011). Market segmentation on wine tourism: a comparison of approaches. Tourismos: An International Multidisciplinary Journal of Tourism, Volume 6, Number 1, UDC: $338.48+640(050)$

Blazheska, D., Nickova, M. (2016). Creating Marketing Strategies for Development of the Wine Tourism. International Journal of Academic Research in Accounting, Finance and Management Sciences, Vol. 6, No. 4, pp. 177-184

Booth, A., Cardona-Sosa, L. \& Nolen, P. (2014). Gender differences in risk aversion: Do single-sex environments affect their development?. Journal of Economic Behavior and Organization, 99(1), pp. 126-154, DOI: 10.1016/j.jebo.2013.12.017

Cant, M.C., Strydom, J.W., Jooste, C.J. \& Du Plessis, P.J. (2007). Marketing management. $5^{\text {th }}$ edition. Cape Town, South Africa: Juta.

De la Broquère, B. (2002). Putopis - putovanje preko mora, Čigoja štampa, Beograd

Fernández, A. G., Ruiz, L. M., Gómez, E. R. D. (2018). Wine Tourism and Wine Marketing in Family-Owned Micro Wineries in Guadalupe Valley, Mexico. Rosa dos Ventos, vol. 10, no. 4, DOI: https://doi.org/10.18226/21789061.v10i4p690

Gregorić, M. (2014). Pestel Analysis of Tourism Destinations in the Perspective of Business Tourism (Mice). Tourism and Hospitality Industry 2014, Congress Proceedings Trends in Tourism and Hospitality Industry, pp. 551-565. 
Hall, C.M., \& Mitchell, R. (2002). The tourist terroir of New Zealand wine: the importance of region in the wine tourism experience. In A. Montanari (Eds.) Food and Environment: Geographies of Taste, Rome: Societa Geografica Italiana.

Ivanova, S., Kireva, K., Dimitrov, D. (2017). On the way to the Thracian wine. Journal of Mountain Agriculture on the Balkans, 20 (4), 168-177.

Kotler, P. \& Armstrong, G. (2006). Principles of marketing. 11th edition. Upper Saddle River, NJ: Prentice-Hall.

Maksimović, M., Pivac, T. \& Alkier, R. (2019): Constantinople Wine Route - A New Wine Tourism Project in the Balkans. ToSEE - Tourism in Sothern and Eastern Europe, Vol.5, pp. 419-430, ISSN 1848-4050, https://doi.org/10.20867/tosee.05.43

Marzo-Navarro, M. \& Pedraja-Iglesias, M. (2009). Wine tourism development from the perspective of the potential tourist in Spain. International Journal of Contemporary Hospitality management, Vol. 21, No. 7, 816-835. https://doi.org/10.1108/09596110910985304

Mitchell, R. (2006). Influences on post-visit wine purchase (and non-purchase) by New Zealand winery visitors. In J. Carlsen and S. Charters (Eds.) Global Wine Tourism: Research Management and Marketing, London: CABI Publishing.

Pratt, M. (2014). Four wine tourist profiles. $8^{\text {th }}$ International Conference, Academy of Wine Business Research, Geisenheim, Germany

Strategija razvoja turizma Srbije 2016-2025, https://mtt.gov.rs/download/3/strategija.pdf (11.11.2019.)

Zirojević, O. (1970). Carigradski drum od Beograda do Sofije (1459-1683). Zbornik Istorijskog muzeja Srbije 7, Beograd. 